\title{
Effect of Budget Discretion on Corruption Level and Public Accountability: Evidence from Local Indonesian Government
}

\author{
Annisa Febrian \\ Master's Degree Student \\ Faculty of Economics and Business, Universitas Indonesia \\ Depok, Indonesia \\ annissa@ui.ac.id
}

\author{
Hilda Rossieta* \\ Associate Professor \\ Faculty of Economics and Business, Universitas Indonesia \\ Depok, Indonesia \\ enjum9@gmail.com, hilda.rosieta@ui.ac.id
}

\begin{abstract}
This research investigates whether the level of corruption and public accountability of local government budgets differ between discretionary and non-discretionary types. This quantitative research uses secondary data of criminal law from the Attorney General. Accordingly, corruption cases related to misappropriation of budgets from Year 2010-2016 are used as the research sample. The results show that corruption cases of misappropriation in discretionary and non-discretionary budgets are indifferent. This indicates that the level of financial loss of the State is not associated with the type of budget. However, further tests show that there are differences in financial losses between high and low discretionary budgets. This means that, the higher the level of budget discretion, the bigger the opportunities of corruption. This research finds contrasting findings with regards to the accountability level, revealing differences between discretionary and non-discretionary budget cases.
\end{abstract}

Keywords-corruption, discretionary budget, nondiscretionary budget, grant and social assistance budget, procurement budget

\section{INTRODUCTION}

Corruption in Indonesia has not yet been completely eradicated. The 2016 Transparency International survey results stated that Indonesia ranked 90th with a corruption perception index (CPI) of 37, down from 88 out of 176 in 2015 [1]. According to the Indonesia Corruption Eradication Commission (KPK), statistics show that, from 2004 through 2017 , out of 688 corruption cases, $40.7 \%$ occurred in local governments (i.e., provincial, district, city). Additionally, the Indonesian Corruption Watch (ICW) documented that, out of 226 corruption cases during the first semester of 2017, 121 cases occurred in local government [2].

Data released by ICW in 2015 stated that budget misappropriation was the most popular mode of corruption. Within those, fictitious reports, budget misuse, price markups fair price, and use of state budget for personal interest were discovered. According to the ICW, there were 154 cases of budget misappropriation in 2017 with financial losses reaching Rp1.2 trillion [3], in which most cases occurred in local governments.

Budget misappropriations occur mostly in two categories, namely: social assistance/grants and procurement. Social assistance and grant budgets are controlled by the government official whose purview is the financial capacity of the region affected [4]. Research found that the relationship between social assistance and grant budgets increased during local elections, as did misappropriations of both types of budgets [4]. Additionally, the KPK found the same correlation. Empirical evidence suggests that the main cause of most corruption is budget misappropriation [5]. The second type of budget vulnerable to misappropriation is the procurement and capital expenditure budget [6]. Public procurement becomes the main area of corruption, especially at the local government level [7]. Some argued that misappropriation was exacerbated by public managers' authority to design agreements potentially beneficial for both governments and businesses [8].

Previous studies of budgets and corruption show positive association between budget characteristics with the level of corruption [9][10][11][12]. Empirical evidences showed that the higher budget, the higher level of corruption. Few studies, if any, have addressed corruption cases at the local government level. Most studies focused on the size of the country budget as measured by gross domestic product and CPI. Moreover, empirical evidence suggested the same, specifically in the Indonesian context. Research regarding local government corruption is important for this context, particularly after the adoption of the balanced-budget policy between central and local government, as stated in Law No. $33 / 2004$.

This research examines whether corruption levels and public accountability for discretionary budgets at local government levels in Indonesia, including grants and social assistance budgets, differ from those of non-discretionary budgets. This research provides several contributions to the literature. First, it measures levels of corruption based on real cases of misappropriation as documented by the Attorney General of Indonesian. Thus, this research has better external validity compared to previous studies that mostly used CPI as proxies of corruption. Second, this research links the corruption level to public managers' discretionary budgetary level. Accordingly, this research classifies budget misappropriation into two types: discretionary and nondiscretionary. Assuming an agency problem in which management tends to maximize their utility value at the cost of others, corruption is logically more likely to occur with a discretionary budget. Therefore, using different types of budgets as samples improves the external validity of this research. Third, this research considers the role of public 
accountability, especially the assurance of external audits, in preventing corruption opportunities.

\section{LITERATURE REVIEW AND HYPOTHESES DEVELOPMENT}

\section{A. Theoretical Foundation: Agency Theory in the Public Sector}

Agency theory was first introduced by Jensen and Meckling [13], who stated there was a relationship of disharmony between principals and agents. A principal is A party that gives an agent a task, and an agent is a party that accepts the task, based on a contract with a principal. The relationship may cause agency problems because of differences in objectives between the principal and agent. This agency problem is caused by information asymmetry, which leads to opportunistic acts and moral hazards.

Principal and agent relationships exist in private entities between shareholders and management. Multiple agency relationships in the public sector are far more complex. The first agency relationship to note is between the people (principals) who own the vote and parliament members (agents) who performs the legislative function [14]. The second agency relationship is between the people and the government. The people, as principals, can directly elect the president or the regional heads, whereas the president or the regional heads carry out their executive functions in accordance with the people's interests. The third agency relationship is that between the central and local governments. Referring to Law No. 23/2014, the local government is authorized by the central government to manage local affairs, such that their executive autonomy outlined by the Act becomes the contracted agency relationship.

Based on research conducted by Latifah [15], agency relationships in government generate opportunistic behaviors because of the information asymmetry between the principals and the agents. The government has more information than the people, and the people have limited understanding of government activities. One form of opportunistic agent behavior is corruption. Corruption is defined as the abuse or misuse of money belonging to entities such as the state, companies, organizations, or foundations. According to Law No. 31, regarding the eradication of corruption, corruption is defined as the act of a person with the purpose of benefiting himself or others or a corporation, misusing authority because of the position, resulting in financial or economic losses. Inappropriate political representation and weak institutional infrastructure provide windows of opportunity for corruption, particularly during the budgeting process [15].

\section{B. Hypothesis Development}

1) Discretionary budget, corruption opportunity, and financial loss

Based on Law No. 17/2003, regarding state finance, the president is in charge of the management of state finances, as delegated to the finance minister, the institution head, or the governor/regent/mayor. The transfer of power affects the preparation of state and the local budgets each year. With the agency theory, the granting of these powers can lead to misuse of authority in the form of corruption.
In Law No. 30/2014, regarding government administration, discretion or authority is a decision or an action determined and performed by government officials to address concrete problems faced in governance. Law No. 17/2003 addressed the issues of budgeting and financial management. Still, the Indonesian Forum for Budget Transparency (FITRA) [16] found corruption occurring during the budgeting process associated with government officials' discretion and abuse of power. Local governments prepare a local expenditure budget (APBD). An expenditure budget is classified by its purpose: personnel, procurement, grant, social assistance, or capital. Owing to unclear outcomes, high management discretion is required. Grants and social assistance moneys are considered among the most vulnerable for misappropriation. This type of budget is covered under the Regulation of the Minister of Home Affairs of the Republic of Indonesia (Permendagri) No. 14/2016. Article 4 states that local governments can grant local moneys according to financial capacity, meeting minimum criteria as follows: non-mandatory; non-binding and non-recurring; supporting the implementation of government functions; and meeting the requirements of the grantee. Article 22 states that local governments can also provide social assistance to member/community groups according to the financial capacity of the region after prioritizing the fulfillment of compulsory and optional affairs. However, the terms of social assistance are not defined clearly, creating uncertainty about the interpretation, specifically regarding what should be included.

From regulation of Permendagri No.14/2016, major consideration for determining grants and social assistance budget is financial capacity of the local government. Considering government officials is the agent who has the most information regarding local financial capacity, hence, decision regarding the use of social grants and funds is entirely under their discretion and authority. Winoto and Falikhatun [4] stated that grants and social assistance budgets are discretionary funds whose budget determination tends to be subjective. Research conducted by Winoto and Falikhatun [17] found that the greater the fiscal space (local financial capacity) the greater the flexibility of its allocation to local expenditure, including grants and social expenditures. In addition, research of Ritonga and Alam [18] found indications of irregularities in APBD, especially in grant and social assistance budget prior to the election. The KPK research also concludes that during the election period, social assistance fund and APBD grants are increased as well as many corruption cases caused by budget misappropriation [5].

In summary, the potential for corruption can occur with a discretionary budget, depending to a great extent on government officials as public agents. Considering grants and social assistance budgets as a type of discretionary budget, this research argues that the regulations governing these budget items have several weaknesses. Importantly, regulations are not yet binding and have multiple interpretations. Therefore, public managers have unusually high discretion to determine activities and budget targets [19]. Accordingly, the first proposition of this research is as follows:

Proposition 1: Discretionary budget type creates corruption opportunities that leads to financial losses. 
2) Non-discretionary budget, corruption opportunity, and financial loss

The procurement budget is also prone to corruption (Mahmood, 2010). This budget is highly structured with clear and measurable outcomes. Therefore, the need for managerial discretion is low. However, procurement often requires huge amounts of budget to be spent over a multiyear period, providing large windows of opportunity for corruption. According to FITRA, corruption crimes related to misappropriation of APBD mostly occurred with expenditure items having a large percentage of budget allocation, such as procurement or infrastructure. Commonly used modes of corruption are mark-ups, fictitious reports, abuses of authority, and embezzlement.

Based on President Regulation No.16/2018, the procurement of goods and services is an activity by the ministry, institution, or local government funded by the state and local budgets, whose process starts from the identification of a requirement until the handing over of work products. Procurement of goods and services includes materials, construction works, consulting services, and other services. Article 7 regulates the ethics of procurement, stating that, essentially, all parties involved must avoid conflicts of interest, prevent waste and money leaks, and prevent abuses of authority. Until now, most corruption cases involved the procurement of goods and services using mark-ups [20].

Research [21] found that public procurement was a major area of corruption, especially with local governments of Uganda. Corruption is closely related to large and uncommon projects where the main contractor is the public sector/government official [22]. It can thus be concluded that corruption is likely to occur when dealing with large budgets in contexts where regulations remain unbinding. The procurement of goods and services typically requires a large budget. This research, therefore, suggests the following proposition:

Proposition 2: The size of the non-discretionary budget creates corruption that lead to financial losses.

3) Public accountability, corruption opportunity, and type of budget discretion

Based on previous research [23], a method of reducing corruption requires increasing transparency and accountability. This is consistent with Presidential Instruction No. $7 / 2015$ and $10 / 2016$ on the Corruption Prevention and Eradication Act. These regulations demand the coordination of all institutions when conducting corruption prevention actions. Furthermore, implementation of the regulations covers the optimization of licensing policy implementation, governance reform, strengthening of internal control systems and supervision, information disclosure in governance, and increased transparency and accountability of financial management.

Local government accountability is achieved with the report of financial accountability of local management, as required by Law No. 17/2003. Furthermore, audits of financial statements assess and provide assurance regarding government accountability. The Supreme Audit of Indonesia (BPK) is responsible for auditing and interpretations of financial statements. Thus far, public accountability of the state budget is reported in financial statements. Local governments present comprehensive information on their overall accountability [24]. Accountability includes findings related to internal control systems and regulatory compliance.

Some previous studies investigate the associations between the level of accountability with the results of financial statement audit (Ekasari, 2016; Liu \& Lin, 2012; Masyitoh, Wardhani, \& Setyanigrum, 2015)[25][26][27]. Research by Liu and Lin [26] shows that the government audit system plays an important role in improving financial transparency in China. The number of audit findings have a positive effect on corruption in local government while the follow-up from audit findings of previous year has negative effect to corruption in local government. This suggests that audits play important role in limiting corrupt practices. But on the other hand, research of Masyitoh et al., [27] shows that there is no correlation between the weakness of internal control with perceptions of corruption. Research of Ekasari [25] found that accountability as measured by recommendations for follow-up examination results could weaken the positive effect of fiscal decentralization on corruption. Of all studies regarding accountability issues, the issues of budget discretion are hardly addressed. Thus, it can be concluded that, the lower the level of accountability, the higher the chances of public officials practicing corruption. Thus, corruption caused by low levels of accountability cannot be distinguished by the type of budgets.

Preposition 3: Public accountability for budget misappropriation corruption cases is indifferent between discretionary and non-discretionary budgets.

\section{RESEARCH METHODOLOGY}

This research uses a quantitative method with nonparametric test analysis and secondary data with documented cases of corruption and budget data of local governments. The research sample includes corruption case data handled by the Attorney General related to misappropriations of local government budgets from Y 2010-2016. Sample selection was accomplished via purposive sampling with the following criteria: local governments with corruption cases related to grant, social assistance, procurement, capital expenditure budgets; cases of corruption within the time period; and data containing financial losses caused by corruption. Variables of the research are described in Table I.

TABLE I. VARIABLE MEASUREMENT

\begin{tabular}{|l|l|}
\hline \multicolumn{1}{|c|}{ Variable } & \multicolumn{1}{c|}{ Measurement } \\
\hline level & $\begin{array}{l}\text { The level of corruption is obtained from the data of } \\
\text { corruption cases handled by the Attorney General. } \\
\text { Proxy of corruption level is measured by the amount of } \\
\text { financial losses caused by corruption via budget } \\
\text { misappropriation. The amount of state losses is divided } \\
\text { by the amount of discretionary and non-discretionary } \\
\text { budget. }\end{array}$ \\
\hline Public & $\begin{array}{l}\text { Public accountability is obtained from the data of the } \\
\text { local government audit report by the BPK. Proxy is } \\
\text { measured by the average number of findings related to } \\
\text { discretionary/non-discretionary budget corruption (Rp) } \\
\text { divided by the number of findings by BPK. }\end{array}$ \\
\hline
\end{tabular}

This research used the Mann-Whitney non-parametric test to distinguish the mean of the two groups by comparing the variance [28]. The factorial design in this research was 2 
$\times 1$ to test the prepositions. Tables II and III reflect the tests of Proposition 1. Table IV reflects Proposition 2. Table V reflects Proposition 3.

TABLE II. FACTORIAL DESIGN: FINANCIAL LOSS BETWEEN TYPES OF CORRUPTION BUDGET MISAPPROPRIATION

\begin{tabular}{|l|c|c|}
\hline \multirow{2}{*}{ Financial loss } & \multicolumn{2}{|c|}{ Budget } \\
\cline { 2 - 3 } & Discretionary Budget & Non-Discretionary budget \\
\hline
\end{tabular}

TABLE III. FACTORIAL DESIGN: FINANCIAL LOSS BETWEEN DISCRETIONARY BUDGET LEVELS

\begin{tabular}{|l|c|c|}
\hline \multirow{2}{*}{ Financial loss } & \multicolumn{2}{|c|}{ Discretionary Budget } \\
\cline { 2 - 3 } & High & Low \\
\hline
\end{tabular}

TABLE IV. FACTORIAL DESIGN: STATE LOSSES BETWEEN NONDISCRETIONARY BUDGET LEVELS

\begin{tabular}{|l|c|c|}
\hline \multirow{2}{*}{ Financial loss } & \multicolumn{2}{|c|}{ Non-Discretionary Budget } \\
\cline { 2 - 3 } & High & Low \\
\hline
\end{tabular}

TABLE V. FACTORIAL DESIGN: PUBLIC ACCOUNTABILITY BETWEEN TYPES OF CORRUPTION BUDGET MISAPPROPRIATION

\begin{tabular}{|l|c|c|}
\hline \multirow{2}{*}{\begin{tabular}{l} 
Public \\
\cline { 2 - 3 } Accountability
\end{tabular}} & Discretionary Budget & Non-Discretionary budget \\
\hline
\end{tabular}

\section{RESULTS AND DISCUSSION}

\section{A. Descriptive Statistics}

From the 882 corruption cases handled by the Attorney General, there were $38(4.31 \%)$ related to misappropriations of grant and social assistance budgets and $40(4.54 \%)$ related to misappropriation of procurement budgets. More specifically, of the 38 misappropriation cases, 32 occurred in local governments, including Tulungagung (2010 and 2012), Bandung (2012 and 2014), East Java (2010 and 2012), and Bangka Belitung Regency (2011 and 2012). Furthermore, of the 40 procurement cases, 39 occurred with local governments, including Pulang Pisau (2012 and 2013).

Based on Fig. 1, the number of corruption cases related to grants and social assistance budget misappropriations occurred in 2012 (13 cases, 34\%), whereas the number of corruption cases affected by procurement budget misappropriations mostly happened in 2013 (14 cases, 35\%). From the regulation perspective, grant and social assistance guidance was first issued by the Minister of Internal Affairs Regulation No. 32/2011 and implemented in 2012. Additionally, the Government Accounting Standards Committee (KSAP) issued technical bulletin (Bultek) 10 about accounting for the social assistance fund in 2011 to provide guidelines for local government on accounting records. Permendagri on grants and social assistance underwent several improvements in 2012 and 2016, and Bultek 19 was issued in 2015. With the regulation being continually adjusted with more stringent arrangements, the number of corruption cases related to grant and social assistance budget misappropriation declined after 2012. The cases of procurement budget misappropriation mostly occurred in 2013. This is in accordance with the results of ICW's review, which found that the trend of corruption in 2013 (>40\%) was dominated by procurement cases [29].

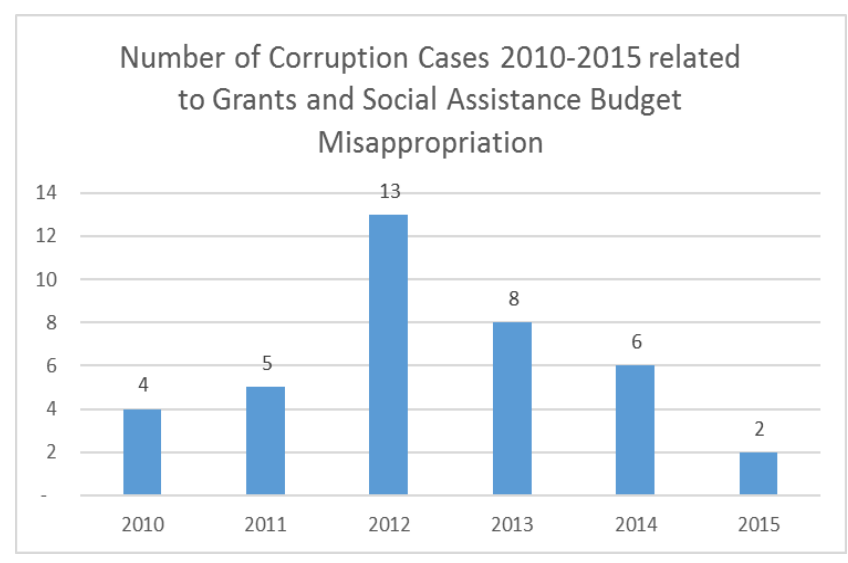

Fig. 1. Number of corruption cases 2010-2015 related to grants and social assistance budget misappropriation.

\section{Number of Corruption Cases 2010-2015 related to Procurement Budget Misappropriation}

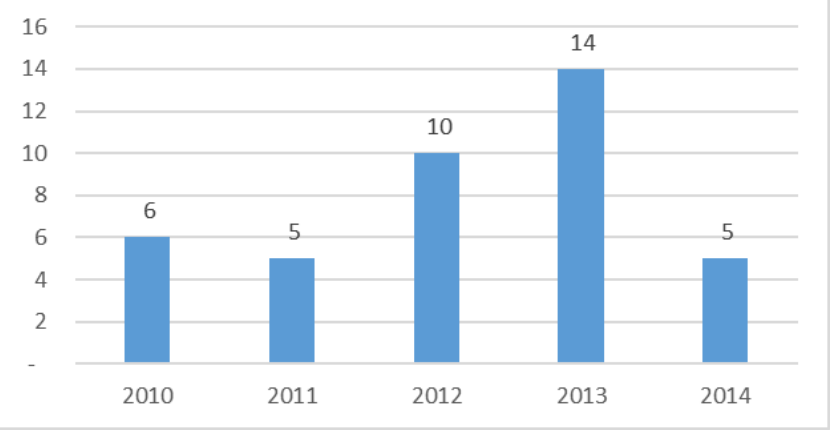

Fig. 2. Number of corruption cases 2010-2015 related to procurement budget misappropriation.

The BPK assesses the fairness of financial statements by providing an audit opinion in accordance with the facts. Based on Fig. 2, the BPK mostly grants unqualified opinion to the local governments affected by corruption, either by misappropriation of grant and social assistance (i,e, 20 cases or $53 \%$ ) or procurement budget (i.e., 25 cases or $63 \%$ ). This agrees with the research of Masyitoh et al. [28], which stated that audit opinions were not related to the level of corruption in Indonesia.

In the BPK financial audit report, there are results of examination of the internal control system and of the examination of the compliance of legislation in the form of findings of irregularities, report discrepancies, and waste. From the results of the examination, there are findings related to grant and procurement budget misappropriations. Based on Fig. 3, of the local governments affected by these two types of corruption cases, $84 \%$ involved grant and social assistance budgets, and $87 \%$ involved procurement budgets. This indicates that the findings of BPK could be the basis for law enforcement officers conducting investigations into corruption cases. 


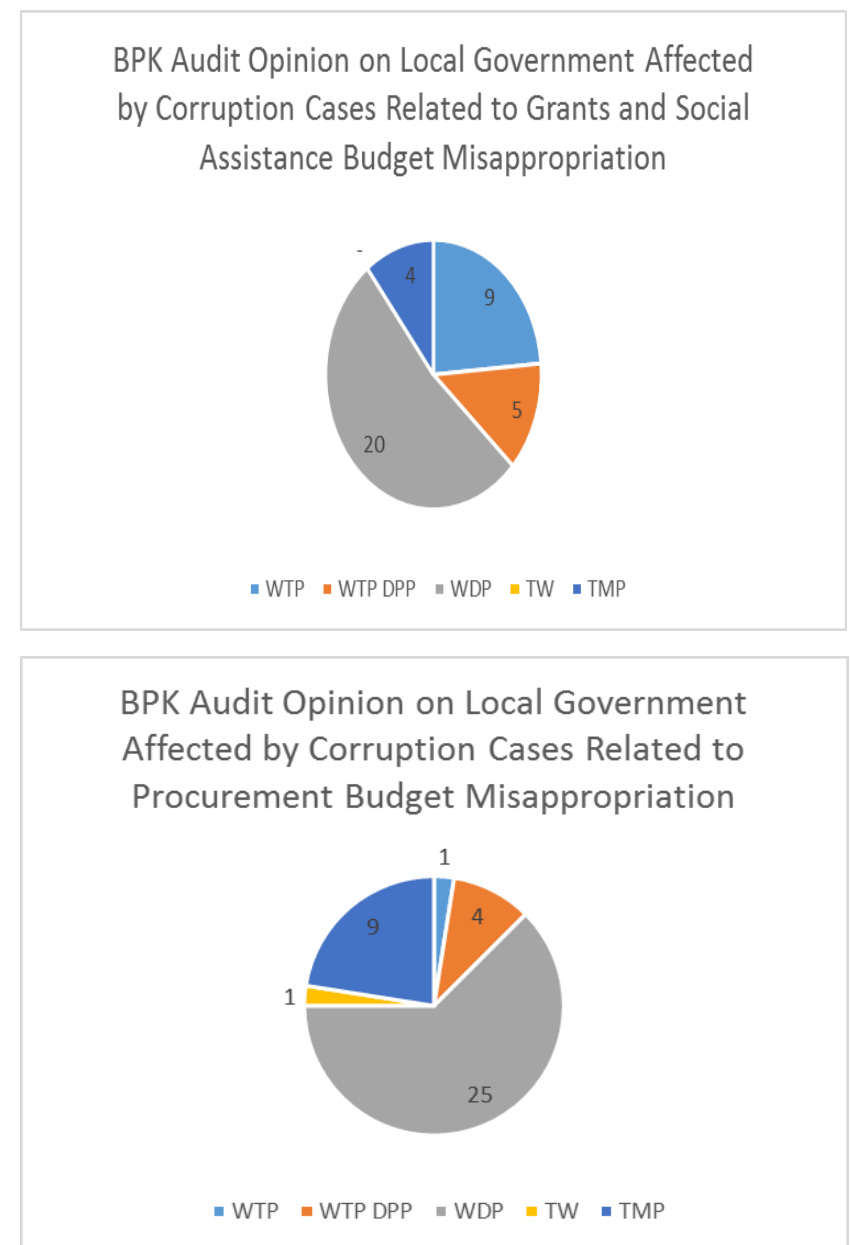

Notes: i) WTP: unqualified opinion; ii) WTP DPP: unqualified opinion with explanatory paragraph; iii) WDP: qualified opinion; iv) TW: unfair opinion; v) TMP : disclaimer

Fig. 3. BPK audit opinion on local government affected by corruption cases related to grants and social assistance budget and procurement budget misappropriation.

\section{Findings of BPK related Grants and Social Assistance Budget Misappropriation}

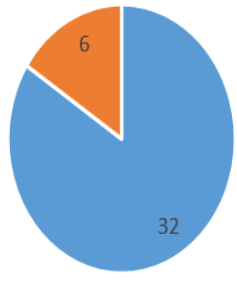

- Yes $=$ No

Fig. 4. Findings of BPK related grants and social assistance budget.

Table VI shows descriptive statistics of financial losses for local government groups affected by corruption cases of discretionary budget misappropriation (group disc) and nondiscretionary budgets (group non-disc) misappropriation. The percentage of financial loss is calculated with the proportion of state financial losses divided by total discretionary (disc) or non-discretionary (non-disc) budgets. The average financial-loss group disc is $1.85 \%$, while the average state losses group non-disc is $1.65 \%$. This indicates that the average financial losses of both groups are not too different. The lowest financial losses are $0.004 \%$ for the disc group and $0.01 \%$ for the non-disc group. The maximum value of state losses between the disc and non-disc groups is about $20 \%$.

\section{Findings of BPK related Procurement Budget Misappropriation}

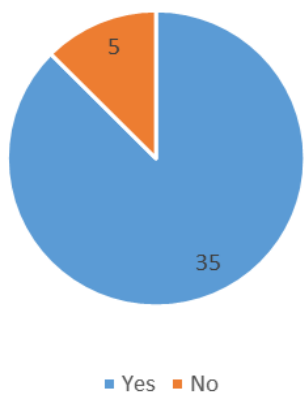

Fig. 5. Findings of BPK related procurement budget misappropriation.

TABLE VI. Descriptive Statistics of FinANCIAL Losses

\begin{tabular}{|c|c|c|c|c|c|}
\hline Variable & Obs & Mean & Std.Dev & Min & Max \\
\hline Groupdisc. & 37 & 0.0185 & 0.0389 & 0.00004 & 0.2015 \\
\hline Groupnondisc. & 40 & 0.0165 & 0.0428 & 0.0001 & 0.2152 \\
\hline
\end{tabular}

Table VII shows descriptive statistics of the percentage of the grant and social assistance budget (group disc) and the procurement budget (group non-disc). The percentage of the grant budget is calculated by adding the grant and social assistance budgets divided by total expenditures. The percentage of the procurement budget is calculated by adding the procurement and capital expenditure budgets divided by total expenditure. The average proportion of disc group budget is $7.85 \%$, whereas the proportion of non-disc group budget is $43.38 \%$. This indicates the size of the procurement budget compared to the grant budget for each local government. The grant and social assistance budget has a small portion, because it is budgeted according to the financial capacity of the local government. The lowest disc group budget is $0.004 \%$ and $21.98 \%$ for the non-disc group. The highest proportion of budget for the disc group is $44.09 \%$, whereas the non-disc group is $72.67 \%$.

TABLE VII. DESCRIPTIVE STATISTICS OF GRANTS AND SOCIAL ASSISTANCE BUdGET AND PROCUREMENT BUDGET

\begin{tabular}{|c|c|c|c|c|c|}
\hline Variable & Obs & Mean & Std.Dev & Min & Max \\
\hline Disc. & 37 & 0.0785 & 0.1024 & 0.0004 & 0.4409 \\
\hline Nondisc. & 40 & 0.4339 & 0.1009 & 0.2198 & 0.7268 \\
\hline
\end{tabular}

\section{B. Empirical Results and Discussion}

The results of Table VIII show that the value of $\mathrm{Z}$ is insignificant, and the p-value is greater than 0.05. Thus, there is no difference in the level of financial loss as a proxy of the 
level of corruption and the corruption groups of discretionary budgets (group disc) and non-discretionary budget (group non disc). This suggests that the extent of corruption is not influenced by the discretionary or non-discretionary nature of the budget.

TABLE VIII. MANN WHITNEY TEST RESUlTS ON THE LEVEL OF CORRUPTION IN DISCRETIONARY AND NON-DISCRETIONARY BUDGETS

\begin{tabular}{|l|c|c|c|c|}
\hline & Obs & Rank Sum & Z & Prob \\
\hline Disc & 38 & 1,590 & 0.890 & 0.3736 \\
\hline Non-disc & 40 & 1,491 & & \\
\hline Total & 67 & 3,081 & & \\
\hline
\end{tabular}

Table IX shows the results of the Mann-Whitney test, in which the value, $Z$, is significant with a $p$-value smaller than 0.05 . This means that there is a difference in the level of state financial loss as a proxy for the level of corruption between the high-disc discretionary group and the low disc budget, supporting Proposition 1. Meaning a local government with a high discretionary budget will create a chance for corruption resulting in higher financial losses. This result is consistent with past research from [18][17], which showed that grant and social assistance budgets were discretionary funds that determined the magnitude of the budget and tended to be subjective [5]

TABLE IX. MANN-WHITNEY TEST RESUltS ON THE LEVEL OF CORRUPTION IN THE Discretionary Budget GROUP

\begin{tabular}{|l|c|c|c|c|}
\hline & Obs & Rank Sum & Z & Prob \\
\hline High Disc & 10 & 95 & -3.315 & 0.0009 \\
\hline Low Disc & 28 & 646 & & \\
\hline Total & 38 & 741 & & \\
\hline
\end{tabular}

Table X shows the result of a Mann-Whitney test on the extent of corruption in non-discretionary budgets. The result shows that the $\mathrm{Z}$ value is not significant, having a $\mathrm{p}$-value greater than 0.05 . This means that there is no difference in the level of financial losses between the non-discretionary budget groups as measured by the high non discs and low non-discs. This result does not support Proposition 2. Thus, the high level of non-discretionary budget (e.g., procurement budget) is not related to the level of financial losses. This could be caused by the procurement budget of goods and services being no more subjective, adjusted to the needs of the local government. Additionally, procurement budgets require a more stringent planning mechanism because of the large proportion of the total budget.

TABLE X. MANN-WHITNEY TEST RESULTS ON THE LEVEL OF CORRUPTION IN THE NON-DISCRETIONARY BUDGET GROUP

\begin{tabular}{|l|r|r|r|c|}
\hline & Obs & Rank Sum & Z & Prob \\
\hline High Non-Disc & 20 & 362 & -1.298 & 0.1941 \\
\hline Low Non-Disc & 20 & 458 & & \\
\hline Total & 40 & 820 & & \\
\end{tabular}

Table XI shows the results of a Mann-Whitney test on accountability levels of discretionary and non-discretionary budgets. The results show that the value of $\mathrm{Z}$ was significant with a p-value smaller than 0.05 . This means that there is a difference in the level of accountability between the discretionary and non-discretionary budget groups. This does not support Proposition 3.
TABLE XI. MANN-WhitNEY TEST RESUlTS ON ACCOUNTABILITY LEVELS IN DISCRETIONARY AND NON-DISCRETIONARY BUDGETS

\begin{tabular}{|l|r|r|r|c|}
\hline & Obs & Rank Sum & Z & Prob \\
\hline Disc & 32 & 1350 & 3.289 & 0.0010 \\
\hline NonDisc & 35 & 928 & & \\
\hline Total & 40 & 2278 & & \\
\hline
\end{tabular}

\section{CONCLUSION}

Corruption in Indonesia has not been effectively, particularly related to local government budget misappropriations. Two types of expenditures are often indicated for misappropriation: grant/social assistance and procurement budgets. The grant and social assistance budget is discretionary in nature, making it subjective. Budget determination is based on the capability of each local government. The procurement budget is non-discretionary, and budget determination is based on the need of the local government to support operations and sustainment of the government. This research aimed to determine whether there were differences in levels of corruption and accountability between discretionary and non-discretionary budgets. The results show that there was no difference in the level of corruption (financial loss level) between the discretionary and non-discretionary budgets. Thus, the financial loss level is unaffected by the discretionary or non-discretionary differences. However, there are differences in financial losses between high and low discretionary budgets. This suggests that, the greater the level of discretion, the greater the chances of corruption, which can lead to high financial losses. In terms of accountability, there is a difference between discretionary and non-discretionary budget cases. This shows that accountability levels are influenced by discretionary and non-discretionary budget-group differences.

This research has some limitations. First, corruption data comprise case data handled by the Attorney General, whose information is limited on financial losses caused by the corruption. Further research should leverage more complete and comprehensive case data from police corruption units and the KPK. Second, this research focused on FYs 20102016. Future research could leverage a longer range of budget years, so that more corruption data could be obtained. This research only examined the role of BPK as an external auditor, related to audit findings in the internal control system and compliance laws related to budget misappropriation. Further research should consider factors from internal auditors, such as the government's internal control apparatus, including capability and maturity level and the maturity of the control system used to prevent fraud and corruption.

\section{REFERENCES}

[1] Transparency International. (2016). Corruption Perceptions Index 2016. Transparency International. https://doi.org/978-3-943497-18-2

[2] Hariyanto, I. (n.d.). ICW: Dalam 6 Bulan, 226 Kasus Korupsi Rugikan Negara Rp 1,83 T. 2017. Retrieved from https://news.detik.com/berita/d-3621894/icw-dalam-6-bulan-226kasus-korupsi-rugikan-negara-rp-183-t

[3] Detik.com. (2018). ICW: Korupsi Pengadaan Barang 2017 Meningkat, Negara Rugi Rp $1 \mathrm{~T}$.

[4] (Winoto \& Falikhatun, 2015b)

[5] Komisi Pemberantasan Korupsi. (2014). Cegah Dana Bansos dan Hibah dari Penyalahgunaan. 
[6] Mahmood, S. A. I. (2010). Public procurement and corruption in Bangladesh confronting the challenges and opportunities. Journal of Public Administration and Policy Research, 2(6), 103-111.

[7] Thai, K. V. (2008). Measuring losses to pu blic procurement corruption: the Uganda case. 3rd International Public Procurement Conference Proceedings.

[8] Neu, D., Everett, J., \& Rahaman, A. S. (2015). Preventing corruption within government procurement: Constructing the disciplined and ethical subject. Critical Perspectives on Accounting, 28, 49-61. https://doi.org/10.1016/j.cpa.2014.03.012

[9] Bonaglia, F., Macedo, J. De, \& Bussolo, M. (2001). How globalisation improves governance. Development, 181(181), 1-38. https://doi.org/10.1787/774554632487

[10] Lessmann, C., \& Markwardt, G. (2010). One Size Fits All? Decentralization, Corruption, and the Monitoring of Bureaucrats. World Development, 38(4), 631-646. https://doi.org/10.1016/ j.worlddev.2009.11.003

[11] Mauro, 1998

[12] Windarti, A. (2015). Pengaruh Anggaran Belanja Daerah dan Senjangan Anggaran Terhadap Tingkat Korupsi di Indonesia.

[13] Jensen, M., \& Meckling, W. (1976). Theory of the firm: Managerial behavior, agency costs and ownership structure. Journal of Financial Economics, 3, 305-360. https://doi.org/10.1016/0304-405X(76) 90026-X

[14] Halim, A., \& Abdullah, S. (2006). Hubungan dan masalah keagenan di pemerintah daerah: (Sebuah Peluang Penelitian Anggaran dan Akuntansi. JURNAL BPPK

[15] Latifah, N. (2010). Adakah perilaku oportunistik dalam APLIKASI agency theory di sektor publik? Fokus Ekonomi, 5, 85-94.

[16] Mauro, P. (1998). Corruption and the composition of government expenditure. Journal of Public Economics, 69(2), 263-279. https://doi.org/10.1016/S0047-2727(98)00025-5

[17] Winoto, A. H., \& Falikhatun. (2015a). Indikasi Penyalahgunaan Discretionary Fund dalam Anggaran Pendapatan dan Belanja Daerah Menjelang Pemilukada 2015. Jurnal Akuntansi Dan Keuangan Indonesia, 12, 75-91

[18] Ritonga, I. T., \& Alam, M. I. (2010). Apakah Incumbent Memanfaatkan Anggaran Pendapatan dan Belanja Daerah (APBD) untuk Mencalonkan Kembali Dalam Pemilihan Umum Kepala Daerah. Simposium Nasional Akuntansi XIII Purwokerto, (4), 1-25.

[19] KSAP. (2015). Buletin Teknis SAP No.19 tentang Akuntansi Bantuan Sosial Berbasis Akrual.

[20] Komisi Pemberantasan Korupsi. (2018). Kajian Pencegahan Korupsi pada Pengadaan Barang dan Jasa Pemerintah.

[21] (Thai, 2007)

[22] Locatelli, G., Mariani, G., Sainati, T., \& Greco, M. (2017). Corruption in public projects and megaprojects: There is an elephant in the room! International Journal of Project Management, 35(3), 252-268. https://doi.org/10.1016/j.ijproman.2016.09.010

[23] Asis, M. G. de. (2006). Reducing Corruption at the Local Level. World Bank Institute.

[24] Afriyanti, D., Sabanu, H. G., \& Noor, F. (2015). Penilaian Indeks Akuntabilitas Instansi Pemerintah. BPK RI,

[25] Ekasari, P. W. (2016). Pengaruh Desentralisasi fiskal dan akuntabilitas laporan keuangan terhadap tingkat korupsi pada Pemerintah Daerah di Indonesia.

[26] Liu, J., \& Lin, B. (2012). Government auditing and corruption control: Evidence from China's provincial panel data. China Journal of Accounting Research, 5(2), 163-186. https://doi.org/10.1016/ j.cjar.2012.01.002

[27] Masyitoh, R. D., Wardhani, R., \& Setyanigrum, D. (2015). Pengaruh Opini Audit, Temuan Audit, dan Tindak Lanjut Hasil Audit terhadap Persepsi Korupsi pada Pemerintah Daerah Tingkat II Tahun 20082010. Seminar Nasional Akuntansi 18 Universitas Sumatera Utara Medan, 1-26.

[28] Ghozali, Imam.. (2009) Aplikasi Analisis Multivariate dengan Program SPSS. Badan Penerbit Universitas Diponegoro, Semarang

[29] ICW. (n.d.). Tren Korupsi 2013: 1.271 Tersangka, Kebanyakan Incar Pengadaan Barang dan Jasa Artikel ini telah tayang di Tribunnews.com dengan judul Tren Korupsi 2013: 1.271 Tersangka, Kebanyakan Incar Pengadaan Barang dan Jasa, http://www.tribunnews.com/nasional/2014/. 2014. Retrieved from http://www.tribunnews.com/nasional/2014/02/02/tren-korupsi-20131271-tersangka-kebanyakan-incar-pengadaan-barang-dan-jasa 